\title{
Long-Term Results of Cultured Autologous Oral Mucosa Epithelial Cell- Sheet (CAOMECS) Graft for the Treatment of Blindness Due to Bilateral Limbal Stem Cell Deficiency
}

\author{
Kocaba $V^{1 *}$, Thépot $A^{2}$, Yamato $M^{5}$, Daisuke $M^{5}$, Kellal $M^{2}$, Mojallal $A^{1}$, Damour $\mathbf{O}^{3,4}$ and Burillon $C^{1}$ \\ ${ }^{1}$ Hospices Civils de Lyon, Hôpital Edouard Herriot, service d'Ophtalmologie, F-69003, Lyon, France \\ ${ }^{2}$ Cell Seed France, Hôspital Edouard Herriot, Banque de tissus et cellules, F-69003, Lyon, France \\ ${ }^{3}$ Hospices Civils de Lyon, Hôpital Edouard Herriot, Banque de tissus et cellules, F-69003, France \\ ${ }^{4}$ Institut de Biologie et Chimie des Protéines, CNRS/Université de Lyon UMR5086, Lyon, France \\ ${ }^{5}$ Institute of Advanced Biomedical Engineering and Science, Tokyo Women's Medical University, Japan
}

\begin{abstract}
Purpose: To treat bilateral corneal blindness due to limbal stem cell deficiency (LSCD) thanks to corneal transplant of an autologous epithelium of stem cells cultivated by the oral mucous membrane by the technology UpCell ${ }^{\circledR}$-Insert (CAOMECS for Cultured Autologous Oral Mucosal Epithelial Cell-Sheet).

Methods: The efficacy of a CAOMECS corneal graft was assessed over the long term for 23 out of 26 eyes presenting severe bilateral LSCD. This study follows a clinical trial evaluated, which lasted for 12 months. The major evaluation criterion was visual acuity and the minor criteria were the condition of the epithelium (a composite criterion assessed by grading superficial punctate keratitis, the presence of ulcer, the number and activity of neovessels and the presence of conjunctivalization) and the quality of life (grading of photophobia, dryness and pain). The mean follow-up was of 28 months [18-48 months].

Findings: Visual acuity was increased for 17 patients out of 23 treated $(74 \%)$, the state of the epithelium was improved for 15 patients $(62.5 \%)$ and the quality of life was improved for 22 patients $(95.6 \%)$. For the nine patients with stromal opacity, CAOMECS grafting, reducing limbal neovascularization also made it possible to perform a penetrating keratoplasty (until then impossible because of insufficient stem cells causing acute graft rejection). In this group, visual acuity was increased in $66.7 \%$ of the cases; the state of the epithelium was improved in $66.7 \%$ and the quality of life in $100 \%$.

Interpretation: These long-term results demonstrate that CAOMECS contains the stem cells necessary for the constant renewal of the epithelium and restores the epithelial function of the cornea by delaying neovascularization and conjunctivalization. For patients with healthy stroma, an increase in visual acuity is possible with no other treatment. For those whose stroma is severely deteriorated, penetrating keratoplasty is then possible and improved visual acuity can be achieved. This study demonstrates that CAOMECS graft appears as an innovative and safe treatment for blindness due to LSCD.
\end{abstract}

Keywords: Limbal stem cells; Limbal stem cell deficiency; Stem cell transplantation; Cultivated oral mucosal epithelial transplantation; Keratoplasty

\section{Introduction}

Total Limbal Stem Cells Deficiency (LSCD) corresponds to a dysfunction or destruction of the entire population of limbal epithelial stem cells, resulting in the progressive destruction of the corneal epithelium [1]. This alteration of the corneal surface is responsible for functional signs such as chronic pain, photophobia or dry eye syndrome that can seriously handicap the patient in terms of his or her quality of life. Opacification, neovascularization, and conjunctivalization result in a reduction in visual acuity and possibly blindness [2-5].

During total bilateral LSCD, patients have reached a therapeutic impasse. Autologous grafting of the oral mucosa tissue [6-14] or epithelial cells $[1,5,15-21]$ can be practiced. In a clinical trial performed from 2006 to 2010 [22], we used oral mucosa epithelial cells cultivated on UpCell'-insert (CAOMECS for Cultured Autologous Oral Mucosa Epithelial Cell Sheet), a revolutionary technology using a thermosensitive polymer [23-26] which allowed us to graft a sheet that was transparent, resistant, viable and so adherent that sutureless grafting could be done [22]. The one-year follow up of the 26 treated patients suggested CAOMECS was safe and efficacious for the ocular surface reconstruction of patients with bilateral total LSCD.

Visual acuity can only be used as an evaluation criterion if the epithelium alone is involved or when the epithelium regeneration treatment is associated with a later corneal graft to replace the pathological stroma. To limit the clinical trial bias, the methodologists chose to evaluate the benefits of the CAOMECS treatment alone for one year.

Thus, visual acuity was not retained as a main criterion because

*Corresponding author: Kocaba Viridiana, Hôspital Edouard Herriot, Pavillon C, Ophtalmologie, 5, place d'Arsonval, 69003 Lyon, France, Tel: +33 6181854 39; +33 4721162 11; E-mail: viridiana_k@yahoo.fr

Received February 21, 2014; Accepted March 19, 2014; Published March 21, 2014

Citation: Kocaba V, Thépot A, Yamato M, Daisuke M, Kellal M, et al. (2014) Long-Term Results of Cultured Autologous Oral Mucosa Epithelial Cell-Sheet (CAOMECS) Graft for the Treatment of Blindness Due to Bilateral Limbal Stem Cell Deficiency. J Stem Cell Res Ther 4: 181. doi:10.4172/2157-7633.1000181

Copyright: ( 2014 Kocaba V, et al. This is an open-access article distributed under the terms of the Creative Commons Attribution License, which permits unrestricted use, distribution, and reproduction in any medium, provided the original author and source are credited. 
Citation: Kocaba V, Thépot A, Yamato M, Daisuke M, Kellal M, et al. (2014) Long-Term Results of Cultured Autologous Oral Mucosa Epithelial Cell-Sheet (CAOMECS) Graft for the Treatment of Blindness Due to Bilateral Limbal Stem Cell Deficiency. J Stem Cell Res Ther 4: 181. doi:10.4172/2157-7633.1000181

Page 2 of 8

the allogenic corneal secondary grafting procedures could not be performed during the first year of the follow-up to evaluate the effect of the CAOMECS alone.

The objective of this study was to carry out a long-term evaluation selecting visual acuity as a main evaluation criterion after a long-term follow-up during which the patients who needed corneal grafting could undergo the procedure that was made possible thanks to the presence of functional epithelium.

\section{Material and Methods}

\section{Methodology}

The initial clinical trial, a prospective non-comparative and singleinstitution study was designed according to the Gehan two-stage procedure [27] and conducted according to Good Clinical Practices. In accordance with the Gehan two-stage design, seven patients were included in the first stage. The number of successful procedures three months after the CAOMECS graft during the preliminary phase was used to determine the number of patients required for the follow-up phase (25 according to the initial hypothesis).

\section{Patients}

The research followed the tenets of the Declaration of Helsinki. Informed consent was obtained from the subjects after we had explained the nature and possible consequences of the study. The research was approved by the French Health Products Safety Agency. Twenty-six eyes of 25 patients presenting a LSCD were treated with CAOMECS grafting. The sex ratio was of 16 males to 9 females (1.8) and the patients' mean age was 51 years old [25]. The study concerned 23 eyes of 22 patients (two of them presenting a serious adverse side effect were excluded and one was lost to follow-up); the mean followup was of 28 months (18-48 months).

The 23 treated eyes that remained were divided into two groups:

- Group one $(n=9)$ included the patients with Opaque Corneal Stroma (OCS) limiting visual recovery. The 9 had undergone corneal grafting after the end of the clinical trial (after 12 months).

- Group two $(n=14)$ corresponded to the patients with Clear Corneal Stroma (CCS) or presented moderate opacity that did not warrant keratoplasty.

\section{Treatment procedure}

After enzymatic extraction from a $3 \times 3 \mathrm{~mm}$ biopsy, the cells were seeded on inserts (UpCell'-inserts, CellSeed Inc, Tokyo, Japan [22]), placed in a six-well plate containing mitomycin C inactivated feeder layers, cultured for at least four days after the confluence. Before grafting, the sheet was detached by reducing the temperature by $30^{\circ} \mathrm{C}$ and transferred on the eye with a PVDF ring. Before the CAOMECS transplantation, the conjunctival and subconjunctival scar tissues and all the residual epithelium were removed from the patients' cornea up to $3 \mathrm{~mm}$ outside the limbus to re-expose the corneal stroma. Then, the harvested CAOMECS was placed directly onto the exposed stromal bed. The grafted corneal surface was then covered with a soft contact lens (Night and Day ${ }^{\mathrm{TM}}$, Ciba Vision, Duluth, Georgia, USA) to provide protection during the first few days. After surgery, topical antibiotics $(0.3 \%$ ofloxacin $)$ and corticosteroids $(0.1 \%$ betamethasone $)$ were initially applied four times a day and then three times a day. During the first week after surgery, betamethasone ( $4 \mathrm{mg}$ per day) was administered orally to reduce postoperative inflammation. One month after surgery, the administration of topical corticosteroids was changed from $0.1 \%$ betamethasone to $0.1 \%$ fluorometholone. Since most patients had severe dry eye, preservative-free artificial tears were used at each patient's discretion throughout the study period. Keratoplasties were performed after the 12-month post-CAOMECS (which demonstrated the efficacy of procedure) on nine patients presenting limited visual acuity because of substantial stromal opacification.

\section{Trial outcomes}

Visual acuity: Visual Acuity (VA) was graded on a scale ranging from the light perception to the $10 / 10$ on the Snellen scale. This includes the sight of hand movement (at the distance of 20,50 and $100 \mathrm{~cm}$ ), then counting the fingers (at the distance of 20,50 and $100 \mathrm{~cm}$ ) and finally the Snellen scale $(<1 / 20,1 / 20,1 / 10$ to $10 / 10)$. The visual acuity data were converted to the LogMar scale (conversion of the geometric scale to the arithmetic scale) for analysis. A decrease of a result expressed in LogMar corresponds to an improvement of the VA.

Presence of functional epithelium (Table 1): The quality of the epithelium was estimated by a direct observation using the slit lamp examination with and without the fluorescein test: the evaluation of the epithelial defect, the PEK (Punctate Epithelial Keratitis), and that of the corneal vascularization and the conjunctivalization. Functional signs included photophobia, watering and pain. The scale of each criterion is described in the Table 1. The treatment for a patient was considered a success if an absence of ulcers was observed (Ulcer $=0$ ), an absence or a slight presence of punctate epithelial keratitis ( $\mathrm{PEK}=0$ or + ), an absence of a conjunctival epithelium on the cornea and a decrease in corneal neovascularization which was evaluated by the number of vascular pediculi in each screen as well as their activity level. A successful treatment meant that all five criteria either improved or remained stable if normal at inclusion. The treatment was considered a failure if at least one criterion worsened or if one criterion that was subnormal at inclusion remained stable.

Quality of life (Table 1): The quality of life was defined by an improvement of at least one functional sign (photophobia, watering and/or pain) from inclusion. These endpoints were assessed by an interview with the ophthalmologist as follows: photophobia (no complaint, fear of luminosity corrected by sunglasses, frequent blinking in light, impossibility to open eyes), watering (no complaint, dry, very dry, eye stuck) and pain (no complaint, occasionally, repetitive pain during the day, permanent).

Tolerance: The tolerance was assessed by collecting the adverse effects from the patients throughout the follow-up period.

- Serious adverse events were defined as a serious medical event, hospitalization, a severe disability, or death occurring during the study, whether or not it was related to the treatment.

- Adverse events were defined like all the events occurring during the study, whether or not they were related to the treatment (headaches, flu, etc.)

\section{Description of statistical methods}

The VA means were analyzed statistically using the Student $t$-test, a comparison of the matched means. We analyzed the number of successful patients-the improving of their VA, the quality of their epithelium and their quality of life after a long-term follow-up. The percentage of successful cases was computed with the corresponding $95 \%$ of confidence interval according to Agresti [28]. 
Citation: Kocaba V, Thépot A, Yamato M, Daisuke M, Kellal M, et al. (2014) Long-Term Results of Cultured Autologous Oral Mucosa Epithelial Cell-Sheet (CAOMECS) Graft for the Treatment of Blindness Due to Bilateral Limbal Stem Cell Deficiency. J Stem Cell Res Ther 4: 181. doi:10.4172/2157-7633.1000181

Page 3 of 8

\section{Immunohistochemistry for demonstration of the regenerative potential of CAOMECS}

One year after the CAOMECS graft, the central cornea of 9 patients with an opaque stroma (OCS group) were replaced with an allogenic donor corneal transplant to achieve healthy stroma whose epithelium was carefully removed. The harvested central corneas of 7 of these 9 patients were analyzed by histology and immunohistochemistry. Native cornea and oral mucosal as tissue controls were harvested on dead donors with approval for scientific use.

All the tissues were fixed in $10 \%$ formalin solution (Formalin solution neutral buffered 10\%, Sigma-Aldrich, Saint Quentin Fallavier, France) and embedded in paraffin. Five-micrometer sections were deparaffinized. Hematoxylin and eosin staining was performed using conventional methods.

An indirect immunoperoxidase technique was applied to $5 \mu \mathrm{m}$ thick sections of formalin-fixed, paraffin-embedded tissue. Rabbit antihuman cytokeratin 6 (Anti-Cytokeratin 6 clone EPR1603Y, Abcam, Cambridge, United Kingdom) mouse anti-p63 (p63 clone 4A4, Ventana, Tucson, Arizona, USA) were used for respectively identified differentiated and proliferative cells.

An automated immunostainer was used (Ventana, Tucson, Arizona,USA). Antigen unmasking and immunodetection was performed according to the manufacturer's instructions (Ventana, Tucson, Arizona, USA). The avidin-biotin technique was applied for revelation. Negative controls were obtained by omission of the first antibody.

\section{Results}

Table 2 summarizes all the results evaluated during the CAOMECS follow-up (the baseline, the situation after one year and the final results). Table 2.1 shows the results of the OCS group including patients who received a post-CAOMECS donor graft and Table 2.2 describes the results of the CCS group including the patients whose stroma was healthy.

\section{Visual acuity evaluation (Tables 2 and 3)}

Table 3 gives the evaluation of the VA during the follow-up which is divided into two parts: Table 3.1 for the OCS group and Table 3.2 for the CCS group. They display all the results evaluated at the beginning of the study, after one year and after the long-term follow-up.

\section{Group OCS+CCS $(n=23)$}

For all the patients, the long-term VA increased in $74 \%$ of the cases (17/23 eyes) (Table 3.1). There was a significant difference between the initial and the long-term VA $(1.67$ vs. $1.44, p<0.01)$. The mean VA improvement was equal to 2.3 lines (Table 3.2).

The VA was not improved in $17.4 \%$ of the cases ( $4 / 23$ eyes) and worsened in $8.6 \%$ (2/23 eyes). Moreover, there was no significant difference between the one-year and the long-term VA (1.45 vs. 1.44, $p>0.01)$

\section{OCS Group: patients who underwent secondary CAOMECS corneal transplantation $(n=9)$}

In this group, we only considered the patients who received a post-CAOMECS graft, excluding the patient number 25 and 26 who received simultaneous donor grafts and who were a failure. The VA was increased in $66.7 \%$ (6/9 eyes) (Table 3.1). There was a significant difference between the initial and the long-term VA (1.74 vs. 1.43 , $p<0.01$ ). The mean VA was improved by 3.1 lines (Table 2.2). A

\begin{tabular}{|c|c|c|}
\hline Physical signs & Scale & Scale description \\
\hline Persistant epithelial defect & $0-3$ & $\begin{array}{l}0: \text { no epithelial loss } \\
+: \text { mild (epithelial loss }<5 \mathrm{~mm} \text { diameter }) \\
++: \text { moderate }(>5 \mathrm{~mm}<7 \mathrm{~mm} \text { diameter }) \\
+++: \text { severe }(>7 \mathrm{~mm} \text { diameter })\end{array}$ \\
\hline Punctate epithelial keratitis (PEK) & $0-3$ & $\begin{array}{l}\text { No PEK } \\
+: \text { mild } \\
++: \text { moderate } \\
+++: \text { severe }\end{array}$ \\
\hline Conjunctival epithelium on cornea & $\begin{array}{l}0 \\
+\end{array}$ & $\begin{array}{l}\text { Absence } \\
\text { Presence }\end{array}$ \\
\hline \multirow[b]{2}{*}{ Corneal vascularization } & Number of vascular pediculus near the limbus & Number \\
\hline & Vessels' Activity 0-3 & $\begin{array}{l}0: \text { inactive (absence of blood) } \\
+: \text { vessels of small diameter } \\
++: \text { vessels with different diameter sizes } \\
+++: \text { vessels with large diameters and in the state of vasodilatation only }\end{array}$ \\
\hline Functional signs & Scale & Scale description \\
\hline Photophobia & $0-3$ & $\begin{array}{l}0: \text { no complaint } \\
+: \text { fear of luminosity corrected by sunglasses } \\
++: \text { frequent winking to light } \\
+++: \text { impossibility to open eyes }\end{array}$ \\
\hline Watering & $0-3$ & $\begin{array}{l}0 \text { : no complaint } \\
+: \text { dry } \\
++: \text { very dry } \\
+++: \text { eye stuck }\end{array}$ \\
\hline Pain & $0-3$ & $\begin{array}{l}0: \text { no complaint } \\
+ \text { : occasionally } \\
++: \text { repetitive pain during the day } \\
+++: \text { permanent }\end{array}$ \\
\hline
\end{tabular}

Table 1: Scale of each secondary criterion. 
Citation: Kocaba V, Thépot A, Yamato M, Daisuke M, Kellal M, et al. (2014) Long-Term Results of Cultured Autologous Oral Mucosa Epithelial Cell-Sheet (CAOMECS) Graft for the Treatment of Blindness Due to Bilateral Limbal Stem Cell Deficiency. J Stem Cell Res Ther 4: 181. doi:10.4172/2157-7633.1000181

Page 4 of 8

\begin{tabular}{|c|c|c|c|c|c|c|c|c|c|c|c|c|c|c|c|}
\hline \multirow[b]{2}{*}{ Patient } & \multirow[b]{2}{*}{ Sex } & \multirow[b]{2}{*}{ Age } & \multirow[b]{2}{*}{$\begin{array}{l}\text { Initial } \\
\text { disease }\end{array}$} & \multicolumn{3}{|c|}{ Visual acuity (Log Mar) } & \multicolumn{4}{|c|}{ Functional epithelium } & \multicolumn{3}{|c|}{ Functional signs } & \multirow[b]{2}{*}{$\begin{array}{l}\text { Previous } \\
\text { surgeries }\end{array}$} & \multirow[b]{2}{*}{$\begin{array}{l}\text { Surgeries post } \\
\text { CAOMECS }\end{array}$} \\
\hline & & & & $\begin{array}{l}\text { Years } \\
\text { from } \\
\text { the } \\
\text { event }\end{array}$ & Baseline & $\begin{array}{l}\text { one } \\
\text { year }\end{array}$ & $\begin{array}{l}\text { Long } \\
\text { term }\end{array}$ & Baseline & $\begin{array}{l}\text { one } \\
\text { year }\end{array}$ & $\begin{array}{l}\text { Long } \\
\text { term }\end{array}$ & Baseline & $\begin{array}{l}\text { one } \\
\text { year }\end{array}$ & $\begin{array}{l}\text { Long } \\
\text { term }\end{array}$ & & \\
\hline 001 & M & 48 & $\begin{array}{l}\text { Chemical } \\
\text { burn }\end{array}$ & 26 & 1.9 & 1.7 & 1.9 & No & Yes & Yes & $0 / 2 / 1$ & $0 / 0 / 0$ & $0 / 0 / 0$ & $4 \mathrm{PK}$ & DALK. PK. AM \\
\hline 003 & W & 69 & $\begin{array}{l}\text { Rosacea } \\
\text { keratitis }\end{array}$ & 27 & 2.30 & 1.70 & 1.90 & No & Yes & No & $1 / 2 / 1$ & $1 / 0 / 0$ & $1 / 0 / 1$ & 0 & DALK \\
\hline 006 & M & 70 & $\begin{array}{l}\text { Corneal } \\
\text { burn }\end{array}$ & 36 & 1.00 & 1.70 & 0.80 & No & Yes & Yes & $1 / 1 / 1$ & $1 / 0 / 0$ & $0 / 0 / 0$ & 0 & PK. PK+EEC \\
\hline 007 & M & 54 & $\begin{array}{l}\text { Corneal } \\
\text { burn }\end{array}$ & & 1.70 & 1.90 & 0.70 & No & Yes & Yes & $2 / 2 / 1$ & $1 / 0 / 0$ & $0 / 0 / 0$ & PK & PK \\
\hline 009 & M & 41 & $\begin{array}{l}\text { Lyell } \\
\text { syndrome }\end{array}$ & 20 & 1.70 & 0.70 & 0.40 & No & Yes & Yes & $1 / 2 / 0$ & $0 / 0 / 0$ & $0 / 0 / 0$ & 3 PK. CS & PK \\
\hline 010 & M & 80 & $\begin{array}{l}\text { Rosacea } \\
\text { keratitis }\end{array}$ & 43 & 2.30 & 1.70 & 2.10 & No & Yes & Yes & $1 / 1 / 0$ & $0 / 0 / 0$ & $0 / 0 / 0$ & 0 & DALK \\
\hline 011 & $M$ & 59 & $\begin{array}{l}\text { Corneal } \\
\text { Burn }\end{array}$ & 5 & 1.70 & 1.30 & 0.70 & No & Yes & Yes & $2 / 2 / 0$ & $0 / 0 / 0$ & $0 / 0 / 0$ & 3 PK. CS & PK \\
\hline 018 & $M$ & 60 & $\begin{array}{l}\text { Congenital } \\
\text { aniridia }\end{array}$ & 61 & 0.80 & 1.70 & 1.90 & No & No & No & 2/1/1 & $1 / 0 / 0$ & $1 / 0 / 0$ & CS & DALK \\
\hline 020 & $M$ & 69 & $\begin{array}{l}\text { Groenow } \\
\text { dystrophy }\end{array}$ & 18 & 2.30 & 2.00 & 2.50 & No & Yes & No & $1 / 1 / 0$ & $0 / 0 / 0$ & $0 / 0 / 0$ & $5 \mathrm{PK}$ & PK \\
\hline
\end{tabular}

Table 2.1: Results of OCS group.

\begin{tabular}{|c|c|c|c|c|c|c|c|c|c|c|c|c|c|c|c|}
\hline \multirow[b]{2}{*}{ Patient } & \multirow[b]{2}{*}{ Sex } & \multirow[b]{2}{*}{ Age } & \multirow[b]{2}{*}{ Initial disease } & \multicolumn{4}{|c|}{ Visual acuity (Log Mar) } & \multicolumn{3}{|c|}{ Functional epithelium } & \multicolumn{3}{|c|}{ Functional signs } & \multirow[b]{2}{*}{$\begin{array}{l}\text { Previous } \\
\text { surgeries }\end{array}$} & \multirow[b]{2}{*}{ Surgeries post CAOMECS } \\
\hline & & & & $\begin{array}{l}\text { Years } \\
\text { from } \\
\text { the } \\
\text { event }\end{array}$ & Baseline & $\begin{array}{l}1 \\
\text { year }\end{array}$ & $\begin{array}{l}\text { Long } \\
\text { term }\end{array}$ & Baseline & $\begin{array}{l}\text { one } \\
\text { year }\end{array}$ & $\begin{array}{l}\text { Long } \\
\text { term }\end{array}$ & Baseline & $\begin{array}{l}\text { one } \\
\text { year }\end{array}$ & $\begin{array}{l}\text { Long } \\
\text { term }\end{array}$ & & \\
\hline 002 & W & 38 & $\begin{array}{l}\text { Neuroparalytic } \\
\text { Keratitis }\end{array}$ & 20 & 1.00 & 0.50 & 0.40 & No & Yes & Yes & $1 / 2 / 1$ & $0 / 0 / 0$ & $0 / 0 / 0$ & 0 & 0 \\
\hline 004 & M & 40 & Corneal burn & 1 & 1.60 & 1.00 & 1.30 & No & No & Yes & $2 / 1 / 0$ & $2 / 0 / 0$ & $2 / 0 / 0$ & AM & 0 \\
\hline 008 & M & 61 & $\begin{array}{l}\text { Severe } \\
\text { trachoma }\end{array}$ & 60 & 1.90 & 1.60 & 1.60 & No & Yes & Yes & $2 / 2 / 1$ & $1 / 0 / 0$ & $1 / 0 / 0$ & CS. 2 PK & PK \\
\hline 012 & $M$ & 38 & Corneal burn & 10 & 1.00 & 0.70 & NA & No & Yes & Yes & $2 / 0 / 1$ & $0 / 1 / 0$ & $0 / 1 / 0$ & DALK. AM & 0 \\
\hline 014 & M & 53 & Corneal burn & 5 & 2.30 & 2.30 & 2.10 & No & No & No & $1 / 1 / 1$ & $0 / 1 / 0$ & $0 / 0 / 0$ & AM. PS & $\begin{array}{l}\text { lamellar keratotomy without } \\
\text { cornea graft+AM+CS }\end{array}$ \\
\hline 015 & W & 51 & $\begin{array}{l}\text { Contact lens } \\
\text { hypoxia/ } \\
\text { congenital } \\
\text { cataract }\end{array}$ & & 1.00 & 0.60 & NA & No & Yes & Yes & $2 / 2 / 1$ & $0 / 0 / 0$ & $0 / 0 / 0$ & 0 & 0 \\
\hline 016 & W & 71 & Lyell syndrome & 9 & 2.30 & 2.00 & 2.30 & No & Yes & Yes & $3 / 1 / 1$ & $1 / 0 / 0$ & 0/0/0 & AM. PK & 0 \\
\hline 017 & M & 50 & Lyell syndrome & 5 & 1.30 & 1.00 & 0.60 & No & No & No & $0 / 3 / 0$ & $0 / 0 / 0$ & $0 / 0 / 0$ & AM & 0 \\
\hline 019 & W & 25 & $\begin{array}{l}\text { corneal } \\
\text { opacity due to } \\
\text { cystinosis }\end{array}$ & 23 & 2.30 & 2.30 & 2.30 & No & No & No & 2/1/2 & $0 / 0 / 0$ & 0/0/0 & 0 & 0 \\
\hline 021 & M & 46 & $\begin{array}{l}\text { Keratitis/ } \\
\text { Hepatitis C }\end{array}$ & 14 & 1.00 & 0.70 & 0.50 & No & Yes & Yes & $1 / 0 / 1$ & $0 / 1 / 0$ & $0 / 1 / 0$ & 0 & 0 \\
\hline 022 & W & 38 & $\begin{array}{l}\text { Neuroparalytic } \\
\text { Keratitis }\end{array}$ & 20 & 0.50 & 0.40 & 0.40 & No & Yes & Yes & $2 / 2 / 0$ & $0 / 0 / 0$ & $0 / 0 / 0$ & DALK & 0 \\
\hline 023 & W & 33 & $\begin{array}{l}\text { Congenital } \\
\text { aniridia }\end{array}$ & 33 & 1.90 & 1.90 & 1.70 & No & Yes & Yes & $2 / 1 / 1$ & $0 / 0 / 0$ & $0 / 0 / 0$ & 0 & Trabeculectomy \\
\hline 025 & W & 54 & $\begin{array}{l}\text { Rosacea } \\
\text { keratitis }\end{array}$ & 24 & 2.30 & 2.10 & 2.30 & No & No & No & 2/1/1 & $2 / 1 / 0$ & 0/0/0 & 0 & $\begin{array}{l}\text { simultaneous } \\
\mathrm{PK}+\mathrm{CS}+\mathrm{CAOMECS}\end{array}$ \\
\hline 026 & M & 55 & $\begin{array}{l}\text { Acid corneal } \\
\text { burn }\end{array}$ & 1 & 2.30 & 1.90 & 1.90 & No & No & No & $2 / 0 / 1$ & $2 / 0 / 1$ & $2 / 0 / 1$ & 0 & 0 \\
\hline
\end{tabular}

Table 2.2: Results of CCS group.

Table 2: Results evaluated during CAOMECS follow up at 1 year and at long-term follow-up versus initial results.

Table 2.1 Results of OCS group including patients who received a post-CAOMECS donor graft;

Table 2.2 Results of CCS group including patients whose stroma was healthy.

The results are presented respectively for Photophobia/Dryness/Pain as 0-1-2-3 /0-1-2-3 /0-1-2-3

Improvement at long term $n=16$

Failure of clinical trial (1 year) $n=9$

Woman (W) Man (M) Perforating Keratoplasty (PK) Deep Anterior Lamellar Keratoplasty (DALK) Amniotic Membrane Transplantation (AM), Cataract Surgery (CS),

Palpebral Surgery (PS) 
Citation: Kocaba V, Thépot A, Yamato M, Daisuke M, Kellal M, et al. (2014) Long-Term Results of Cultured Autologous Oral Mucosa Epithelial Cell-Sheet (CAOMECS) Graft for the Treatment of Blindness Due to Bilateral Limbal Stem Cell Deficiency. J Stem Cell Res Ther 4: 181. doi:10.4172/2157-7633.1000181

Page 5 of 8

significant difference was found between the initial, the one-year and the long-term VA (1.74 vs., $1.60, p<0.01 ; 1.60$ vs. $1.43, p<0.01$ ) (Table 3.2). The long-term VA did not improve for 1 patient out of $9(11.1 \%)$. This patient number 001 presented secondary optic nerve atrophy which limited his visual recovery. The long-term VA worsened for 2 patients out of 9 (22.2\%)- patient number 018 whose VA currently remains limited by deep lamellar anterior keratoplasty astigmatism and patient number 020 whose VA remains limited by central epithelial proliferation.

\section{CCS Group: patients who did not undergo a secondary corneal transplantation after CAOMECS $(n=14)$}

The long-term VA increased in $78.5 \%$ of the cases (11/14 eyes) (Table 3.1). There was a significant difference between the initial and the one-year VA $(1.62$ vs. $1.36, p<0.01)$ as well as between the initial VA and the long-term one (1.62 vs. $1.45, p<0.01)$. The mean VA increased by 1.7 line (Table 3.2). Yet, there was no significant difference between the one-year and the long-term VA (1.36 vs. $1.45, p>0.01)$. The VA did not improve for $21.4 \%$ of the patients (3/14) patient number 016 needed corneal grafting because of a central moderate opacification but this could not be performed given substantial stromal thinning. Patient number 019 was a female patient with cystinosis, presenting substantial corneal opacification, who had undergone kidney transplant rejection during the clinical trial. This rejection was responsible for major stromal inflammation, but the patient received a corneal transplant as soon as her renal status was stabilized. For patient number 025, corneal transplantation was not possible because of the presence of a symblepharon, requiring palpebral surgery before the corneal grafting could be performed. None of the patients in this group presented a decrease in the VA.

\section{Intergroup comparison}

The OCS group's initial VA as well as the gain in the VA significantly differed from the CCS group's (initial VA, 1.74 vs. $1.62, p<0.01 ; \Delta$ VA 0.31 vs. $0.17, p<0.01)$. Indeed, in the OCS group we observed a VA improvement (on average 3.1 lines) superior to the CCS group. But, there was no significant difference between the final VA of the OCS group and the CCS one ( 1,43 vs. $1,45, \mathrm{p}>0,01)$.

\section{Condition of the epithelium (Table 4)}

During the clinical trial, after 12 months the success rate was $64 \%$ (16/25 patients). After the long-term follow-up, the condition of the epithelium improved in $62.5 \%$ of the patients (15/23): $66.7 \%(6 / 9)$ in the OCS group who benefit of secondary graft and 64.3\% (9/14) in the CCS group without other treatment than CAOMECS. It did not improve in $26 \%(6 / 23)$ of the all patients together: $22.2 \%(2 / 9)$ in the OCS group vs. $28.5 \%(4 / 14)$ in the CCS group $(p>0.01)$. It deteriorated in $8.5 \%(2 / 23)$ of the cases: $11.1 \%(1 / 9)$ in OCS group vs. $7.2 \%(1 / 14)$ in the CCS group $(p>0.01)$.

\section{Quality of life (Table 5)}

The quality of life improved in $95.6 \%(22 / 23)$ of the patients, $100 \%$ $(9 / 9)$ in the OCS group vs $92.8 \%(13 / 14)$ in the CCS group ( $p>0.01)$. It remained stable for one patient (1/23 of the patients, $0 / 9$ in the OCS group vs $1 / 14$ in the CCS group, $p>0.01)$. It did not worsen for any of the patients.

\section{Tolerance}

Two patients $(7.7 \%)$ presented a serious adverse event during the clinical trial. Patient number 005 presented a corneal perforation seven months after the CAOMECS transplantation. This serious adverse event was not related to treatment since the patient had presented a contralateral corneal perforation a few weeks after the first eye was treated. These corneal perforations were related to an inflammatory flare-up of the underlying disease (Lyell syndrome). Patient number 024 presented 4.5 months after the simultaneous corneal and the CAOMECS transplantation, a massive acute rejection of the corneal graft. This serious adverse event was not related to the CAOMECS graft. Indeed, the patient presented a high number (20) of very active neovessels, which led to the acute rejection of the corneal graft before CAOMECS could have an effect on neovascularization. Five patients presented an adverse event, which were not related to CAOMECS treatment but rather the underlying disease or the local corticosteroid treatment (ocular hypertension). No infections were noted in any of the patients.

\section{Histological and immunohistological analyses (Figures 1 and} 2)

The corneas of the patients who underwent post-CAOMECS penetrating keratoplasty were analyzed. Figure 1 shows the clinical results one year after CAOMECS treatment and the long-term result of two representative examples of OCS group, patient number 003 and number 009 who received a post-CAOMECS keratoplasty. Figure 2 shows histological and immunohistological results of the excised corneas (for the same patients: number 003 and number 009) during the secondary grafting procedure.

\begin{tabular}{|l|c|c|c|}
\hline & $\begin{array}{c}\text { Visual acuity } \\
\text { increase }\end{array}$ & $\begin{array}{c}\text { Visual acuity } \\
\text { steady state }\end{array}$ & $\begin{array}{c}\text { Visual acuity } \\
\text { decrease }\end{array}$ \\
\hline OCS + CCS group & $17 / 23(74 \%)$ & $4 / 23(17.4 \%)$ & $2 / 23(8.6 \%)$ \\
\hline OCS group & $6 / 9(66.7 \%)$ & $1 / 9(11.1 \%)$ & $2 / 9(22.2 \%)$ \\
\hline CCS group & $11 / 14(78.5 \%)$ & $3 / 14(21.4 \%)$ & $0 / 14(7.1 \%)$ \\
\hline
\end{tabular}

Table 3.1: Percentage of visual acuity increase, steady state and decrease.

\begin{tabular}{|l|c|c|c|c|c|}
\hline & \multicolumn{5}{|c|}{ Visual acuity mean (Log Mar) } \\
\cline { 2 - 6 } & Baseline & 1 year & Long term & $\boldsymbol{\Delta ~ V A}_{\text {B }}-$ VA $_{\text {LT }}$ & $\begin{array}{c}\text { Gain in number } \\
\text { of lines }\end{array}$ \\
\hline $\begin{array}{l}\text { OCS + CCS } \\
\text { group }\end{array}$ & 1.67 & 1.45 & 1.44 & 0.23 & 2.3 \\
\hline OCS group & 1.74 & 1.60 & 1.43 & 0.31 & 3.1 \\
\hline CCS group & 1.62 & 1.36 & 1.45 & 0.17 & 1.7 \\
\hline
\end{tabular}

Table 3.2: Average of visual acuity for all the patients and for OCS and CCS group

Table 3: Visual acuity evaluation for all the patients (OCS + CCS group), for patients who received a post-CAOMECS donor graft (OCS group) and for patients whose stroma was healthy (CCS group)

OCS: opaque corneal stroma, CCS: clear corneal stroma, VA: Visual Acuity, VA Visual acuity baseline, $\mathrm{VA}_{\mathrm{LT}}$ : Visual acuity at long term

\begin{tabular}{|c|c|c|c|}
\hline & $\begin{array}{c}\text { Increase of } \\
\text { epithelium condition }\end{array}$ & $\begin{array}{c}\text { Steady state of } \\
\text { epithelium condition }\end{array}$ & $\begin{array}{c}\text { Decrease of } \\
\text { epithelium condition }\end{array}$ \\
\hline $\begin{array}{l}\text { OCS + } \\
\text { CCS group }\end{array}$ & $15 / 23(62.5 \%)$ & $6 / 23(26 \%)$ & $2 / 23(8.5 \%)$ \\
\hline OCS group & $6 / 9(66.7 \%)$ & $2 / 9(22.2 \%)$ & $1 / 9(11.1 \%)$ \\
\hline CCS group & $9 / 14(64.3 \%)$ & $4 / 14(28.5 \%)$ & $1 / 14(7.2 \%)$ \\
\hline
\end{tabular}

Table 4: Condition of the epithelium.

\begin{tabular}{|l|c|c|c|}
\hline & $\begin{array}{c}\text { Increase of } \\
\text { quality of life }\end{array}$ & $\begin{array}{c}\text { Steady state of } \\
\text { quality of life }\end{array}$ & $\begin{array}{c}\text { Decrease of } \\
\text { quality of life }\end{array}$ \\
\hline OCS + CCS group & $22 / 23(95.6 \%)$ & $1 / 23(4.4 \%)$ & $0 / 23(0 \%)$ \\
\hline OCS group & $9 / 9(100 \%)$ & $0 / 9(0 \%)$ & $0 / 9(0 \%)$ \\
\hline CCS group & $13 / 14(92.8 \%)$ & $1 / 14(7.2 \%)$ & $0 / 14(0 \%)$ \\
\hline
\end{tabular}

Table 5: Quality of life. 
Citation: Kocaba V, Thépot A, Yamato M, Daisuke M, Kellal M, et al. (2014) Long-Term Results of Cultured Autologous Oral Mucosa Epithelial Cell-Sheet (CAOMECS) Graft for the Treatment of Blindness Due to Bilateral Limbal Stem Cell Deficiency. J Stem Cell Res Ther 4: 181. doi:10.4172/2157-7633.1000181

Page 6 of 8

The histological analysis: It's carried out on the 7/9 excised corneas at least one year after the CAOMECS grafting from patients who gave their consent for button analysis. The results showed no neovessels. Moreover, no epithelial cell infiltration was observed in the corneal stroma. The regenerated epithelium appeared very close to the normal corneal epithelium. It was multistratified and differentiated in all cases. We also observed that the Bowman's layer destroyed by the disease was not regenerated.

The immunohistological analysis (Figure 2): It was performed on the excised corneas of 4 patients out of 9. The cytokeratin 6 differentiation marker of the oral mucosa was not expressed in the native control cornea. On the other hand, it was expressed in all differentiated layers of the epithelium of the post-CAOMECS trepanned corneas except in the basal proliferative layer. It showed the oral mucosa origin of the new epithelium. As in the native control cornea, for all the excised corneas at least one year after CAOMECS, nearly all the basal cells expressed p63; a proliferation marker more or less expressed depending on the donor, proving the regenerative capability of the CAOMECS procedure.

\section{Discussion}

In bilateral conditions with total LSCD, a cadaveric allograft limbal transplant (KLAL, Keratolimbal allograft) [29-31] or a

Patient number 003 (on the left) and number 009 (on the right)
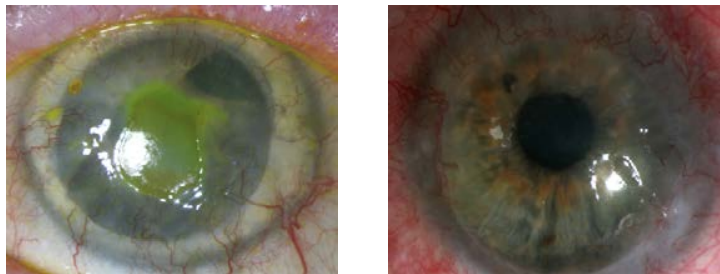

A. Before CAOMECS graft

Note ulcers and active neovascularization
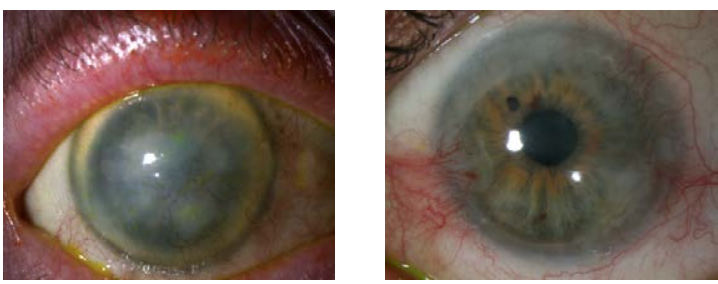

B. One year after CAOMECS graft

Note ulcer and neovascularization regression
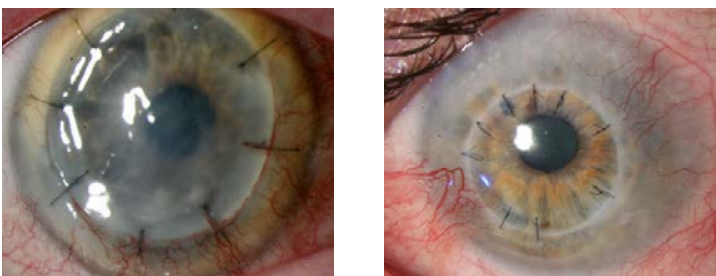

C. One year after Perforating Keratoplasty (2 years after CAOMECS graft)

Absence of rejection sign

Figure 1: Clinical results of two patients

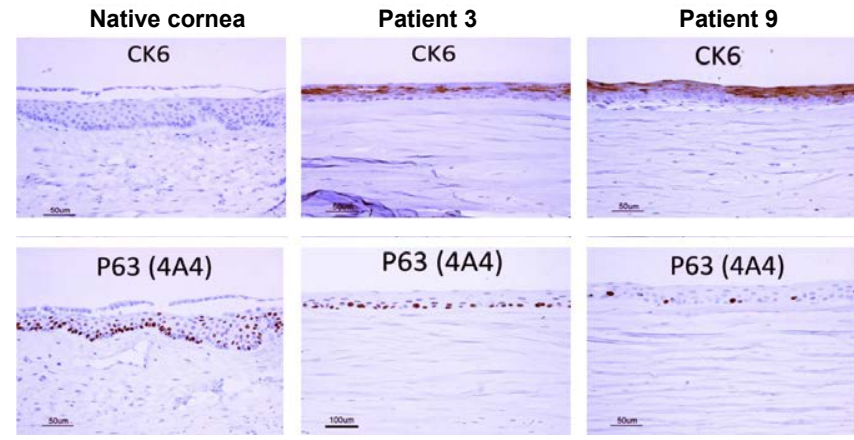

Figure 2: Immunohistological results of corneal trepanation during the secondary grafting procedure. Native control cornea (on the left) compared to same patients shown on the figure 1 (number 003 and 009).

CK6: cytokeratin 6; a differentiation marker of the oral mucosa

CK6 was not expressed in the native control cornea. But it was expressed in all differentiated layers of the epithelium of the post-CAOMECS trepanned corneas except in the basal proliferative layer. It showed the oral mucosa origin of the new epithelium.

P63: Antigen P63, a proliferation marker

As in the native control cornea, for all the excised corneas at least one year after CAOMECS, nearly all the basal cells expressed p63; a proliferation marker more or less expressed depending on the donor, proving the regenerative capability of the CAOMECS procedure.

CLAL (Conjunctival Limbal Allograft) [32] are the main options $[6,9,15,16,33,34]$. Despite immunosuppression, graft outcomes are still unsatisfactory, as rejection and failure frequently occur $[10,11,21,35]$. Another option is the use of COMET (Cultivated Oral Mucosal Epithelial sheet Transplantation) that differs from our technique by cultivating on an amniotic membrane and an enzymatic detachment. Those two steps are not necessary with CAOMECS. In bilateral and asymmetric LSCD, when there are some remaining unaffected regions, CLET (Cultivated Limbal Epithelial Transplantation) from healthy areas of the limbus is another alternative. In CLET, COMET and CAOMECS, the cells are autologous so there are no risks of immunologic rejection and no need for immunosuppression.

Our study confirms that CAOMECS like COMET can improve the VA. Indeed, in this prospective study which evaluated the epithelium stability after the CAOMECS graft, the VA was chosen as the main quantitative criterion to assess a true benefit for the patients $[8,13,18,19]$. It could not be used in the clinical trial for the one-year follow up, because CAOMECS restores the epithelium only and not the stroma. Consequently, when the disease only involves the corneal epithelium, the VA can be increased but when the stroma is also involved, the treatment provides a functional epithelium but the VA cannot be increased. However, by reducing néovascularisation and making the epithelium functional, CAOMECS allows a secondary corneal transplantation without acute rejection. Our data demonstrated that in the opaque corneal stroma (OCS) group, the VA increased after a secondary transplantation in $66.7 \%$ of the cases with a mean gain of 3.1 lines. Moreover, none of these 9 patients presented a cornea graft rejection.

Furthermore, our study shows a significant improvement of the VA already after the one-year follow-up for both groups, even though it was lower for the patients in the OCS group, particularly since these patients had a lower initial VA (mean 1.74 in the OCS group and 1.62 in the CCS group).

Before this clinical trial, one or several keratoplasties failed on 5/9 
Citation: Kocaba V, Thépot A, Yamato M, Daisuke M, Kellal M, et al. (2014) Long-Term Results of Cultured Autologous Oral Mucosa Epithelial Cell-Sheet (CAOMECS) Graft for the Treatment of Blindness Due to Bilateral Limbal Stem Cell Deficiency. J Stem Cell Res Ther 4: 181. doi:10.4172/2157-7633.1000181

Page 7 of 8

patients of the OCS group. This provides an additional argument to prove how successful CAOMECS is. However, for the OCS group, the additional gain in VA between the one-year and the long-term followups was considerable because both epithelium and stroma were treated. This increase was significantly different in the two groups $(p<0 \cdot 01): 3.1$ lines in the OCS group and 1.7 line in the CCS group.

Considering the entire group of eyes treated, $74 \%$ of the 23 eyes treated improved in terms of VA $(66.7 \%$ in the OCS group and $78.5 \%$ in the CCS group), with a mean gain of 2.3 lines. The improvement of the VA thanks to COMET was of $53 \%$ in the study of Nakamura et al. [12] and $48 \%$ in the study of Sotozono et al. [13]. Our results seem to be better-this difference could be explained by the quality of the stem cell sheet. The main advantage of CAOMECS is that no enzymatic treatment is necessary that's why this technology preserves all the proteins of the basal membrane and the intercellular junctions.

Like COMET, CAOMECS offers a viable and safe alternative in the reconstruction of a stable ocular surface [10-14]. The re-establishment of a stable and transparent corneal epithelium, the regression of the corneal conjunctivalization/vascularization, and the resolution of PEK has been considered as criteria of clinical success. Our $62.5 \%$ success rates are close to the ones obtained with COMET [12] demonstrating the potential of the oral mucosa for the epithelial regeneration. In the study of Nakamura et al. [12] with at least a 36 month follow-up, COMET was successful in reconstructing the severely damaged ocular surface. The overall success rate, as measured by the improvement of VA was of 53\%. In another recent study [14] with a mean follow-up period of 25.5 months, there was an early decline in the transplanted oral mucosal epithelial stability over the first six months, which remained comparatively stable thereafter (1 year-64.8\%, 2 years- $59 \%$ and 3 years- $53.1 \%)$.

Moreover, these long-term results demonstrating the presence of a functional epithelium over the long term for $62.5 \%$ of the patients suggest that CAOMECS contains the stem cells necessary for the constant renewal of the epithelium [22-25] and consequently the stability of the benefit for the patients. On the one hand, the VA remained stable over the long term in the CCS group (no significant difference between the one-year and the long-term VA). On the other hand, in the OCS group the VA increased and the histological analysis of the excised cornea harvested during the secondary keratoplasty 12 months after CAOMECS shows a pluristratified and differentiated epithelium very close to the normal cornea epithelium. The expression of p63, a proliferation marker of the epithelium, confirms the continuation of the constant epithelial regeneration. In all the analyzed samples, the suprabasal cells express the cytokeratin 6 . Thus all of it proves the oral mucosa epithelial origin provided by the CAOMECS renewal and not by a cornea or a secondary conjunctival invasion. In other terms, the epithelium cells preserved in the peripheral zone during the secondary grafting were capable of the recolonisation the newly grafted corneal stroma, thereby preserving a stable epithelium over the long term.

Even if the benefit in terms of the VA remains limited for certain patients, it should be remembered that this disease is harmful in their daily life. As the epithelium regenerates and the chronic ulcers disappear, the functional signs greatly diminish. This result is reinforced by the quality-of-life study which shows that $95.6 \%$ of the patients experience an improved life quality.

Like CLET and COMET [10-14,21,35], no complications have been reported concerning any of our patients. Studying the tolerance at this time has shown that the CAOMECS transplantation is well tolerated since neither any adverse effect due to the CAOMECS procedure nor any infection were reported. As for studies about the allogenic stem cell transplantation some cases of infection were reported, these latter cases probably resulted from immunosuppression [15]. In our study, the absence of infection over the short and long terms demonstrates, as stated above, the barrier function against microorganisms of the epithelium regenerated as a result of the CAOMECS procedure.

Our current results concerning the 28-month follow-up [1848 months] demonstrate the efficacy of the CAOMECS transplantation, on 23 eyes of 22 patients by restoring their ocular surface. The VA increased in $74 \%$ of the cases, the quality of life in $95.6 \%$ and the quality of the epithelium in $62.5 \%$.

Our long-term results reveal that the CAOMECS transplantation contains the stem cells necessary to the constant renewal of the epithelium and can restore the epithelial function of the cornea by keeping neovascularization and conjunctivalization in check. For patients with healthy stroma, a better in VA is possible with no other treatment. For those whose stroma is severely altered, penetrating keratoplasty can be performed to develop visual acuity reducing the acute rejection risk

\section{Financial Disclosure}

The authors have no proprietary or commercial interest in any materials discussed in this article.

\section{References}

1. Shortt AJ, Secker GA, Notara MD, Limb GA, Khaw PT, et al. (2007) Transplantation of ex vivo cultured limbal epithelial stem cells: a review of techniques and clinical results. Surv Ophthalmol 52(5): 483-502.[Pubmed]

2. Dua HS, Saini JS, Azuara-Blanco A, Gupta $P(2000)$ Limbal stem cell deficiency concept, aetiology, clinical presentation, diagnosis and management. Indian Ophthalmol 48(2): 83-92.[Pubmed]

3. Puangsricharern V, Tseng SC (1995) Cytologic evidence of corneal diseases with limbal stem cell deficiency. Ophthalmology 102(10): 1476-1485.[Pubmed]

4. Schlötzer-Schrehardt U, Kruse FE (2005) Identification and characterization of limbal stem cells. Exp Eye Res 81(3): 247-264.[Pubmed]

5. Holland EJ, Schwartz GS (1996) The evolution of epithelial transplantation for severe ocular surface disease and a proposed classification system. Cornea 15(6): 549-556.[Pubmed]

6. Santos MS, Gomes JA, Hofling-Lima AL, Rizzo LV, Romano AC, et al (2005) Survival analysis of conjunctival limbal grafts and amniotic membrane transplantation in eyes with total limbal stem cell deficiency. Am J Ophthalmo 140(2): 223-230.[Pubmed]

7. Shore JW, Foster CS, Westfall CT, Rubin PA (1992) Results of buccal mucosa grafting for patients with medically controlled ocular cicatricial pemphigoid Ophthalmology 99(3): 383-395.[Pubmed]

8. Takeda K, Nakamura T, Inatomi T, Sotozono C, Watanabe A, et al. (2011) Ocular surface reconstruction using the combination of autologous cultivated oral mucosal epithelial transplantation and eye lid surgery for severe ocular surface disease. Am J Ophtalomol 152(2): 195-201.[Pubmed]

9. Inatomi T, Nakamura T, Koizumi N, Sotozono C, Yokoi N, et al. (2006) Midterm results on ocular surface reconstruction using cultivated autologous ora mucosal epithelial transplantation. Am J Ophthalmol 141(2): 267-275.[Pubmed]

10. Solomon A, Ellies P, Anderson DF, Touhami A, Grueterich M, et al. (2002) Long-term outcome of keratolimbal allograft with or without penetrating keratoplasty for total limbal stem cell deficiency. Ophthalmology 109(6): 11591166.[Pubmed]

11. Tsubota K, Satake Y, Kaido M, Shinozaki N, Shimmura S, et al. (1999) Treatment of severe ocular-surface disorders with corneal epithelial stem-cell transplantation. N Engl J Med 340(22): 1697-1703.[Pubmed]

12. Nakamura T, Takeda K, Inatomi T, Sotozono C, Kinoshita S (2011) Long-term 
Citation: Kocaba V, Thépot A, Yamato M, Daisuke M, Kellal M, et al. (2014) Long-Term Results of Cultured Autologous Oral Mucosa Epithelial Cell-Sheet (CAOMECS) Graft for the Treatment of Blindness Due to Bilateral Limbal Stem Cell Deficiency. J Stem Cell Res Ther 4: 181. doi:10.4172/2157-7633.1000181

Page 8 of 8

results of autologous cultivated oral mucosal epithelial transplantation in the scar phase of severe ocular surface disorders. Br J Ophthalmol 95(7): 942-946. [Pubmed]

13. Sotozono C, Inatomi T, Nakamura T, Koizumi N, Yokoi N, et al. (2013) Visual improvement after cultivated oral mucosal epithelial transplantation. Ophthalmology 120(1): 193-200.[Pubmed]

14. Satake Y, Higa K, Tsubota K, Shimazaki J (2011) Long-term outcome of cultivated oral mucosal epithelial sheet transplantation in treatment of total limbal stem cell deficiency. Ophthalmology 118(8): 1524-1530.[Pubmed]

15. Tsubota K, Satake Y, Kaido M, Shinozaki N, Shimmura S, et al. (1999) Treatment of severe ocular-surface disorders with corneal epithelial stem-cell transplantation. N Engl J Med 340(22): 1697-1703.[Pubmed]

16. Rao SK, Rajagopal R, Sitalakshmi G, Padmanabhan P (1999) Limba allografting from related live donors for corneal surface reconstruction. Ophthalmology 106(4): 822-828.[Pubmed]

17. Pellegrini G, Traverso CE, Franzi AT, Zingirian M, Cancedda R, et al. (1997) Long-term restoration of damaged corneal surfaces with autologous cultivated corneal epithelium. Lancet 349(9057): 990-993.[Pubmed]

18. Marchini G, Pedrotti E, Pedrotti M, Barbaro V, Di lorio E, et al. (2012) Longterm effectiveness of autologous cultured limbal stem cell grafts in patients with limbal stem cell deficiency due to chemical burns. Clin Experiment Ophthalmo 40(3): 255-267.[Pubmed]

19. Nakamura T, Sotozono C, Bentley AJ, Mano S, Inatomi T, et al. (2010) Longterm phenotypic study after allogeneic cultivated corneal limbal epithelial transplantation for severe ocular surface diseases. Ophthalmology 117(12): 2247-2254.[Pubmed]

20. Kinoshita S (1995) New approaches to human ocular surface epithelium. From basic understanding to clinical applications. In: Kinoshita S, Ohashi Y (eds). 1st Annual Meeting of the Kyoto Cornea Club. Amsterdam/New York: Kugler Publications.

21. Samson CM, Nduaguba C, Baltatzis S, Foster CS (2002) Limbal stem cell transplantation in chronic inflammatory eye disease. Ophthalmology 109(5): 862-868.[Pubmed]

22. Burillon C, Huot L, Justin V, Nataf S, Chapuis F, et al. (2012) Cultured autologous oral mucosal epithelial cell sheet (CAOMECS) transplantation for the treatment of corneal limbal epithelial stem cell deficiency. Invest Ophthalmol Vis Sci 53(3): 1325-1331.[Pubmed]

23. Nishida K, Yamato M, Hayashida Y, Watanabe K, Maeda N, et al. (2004)
Functional bioengineered corneal epithelial sheet grafts from corneal stem cells expanded ex vivo on a temperature-responsive cell culture surface. Transplantation 77(3): 379-385.[Pubmed]

24. Hayashida Y, Nishida K, Yamato M, Watanabe K, Maeda N, et al. (2005) Ocular surface reconstruction using autologous rabbit oral mucosal epithelia sheets fabricated ex vivo on a temperature-responsive culture surface. Invest Ophthalmol Vis Sci 46(5): 1632-1639.[Pubmed]

25. Nishida K, Yamato M, Hayashida Y, Watanabe K, Yamamoto K, et al (2004) Corneal reconstruction with tissue-engineered cell sheets composed of autologous oral mucosal epithelium. N Engl J Med 351(12): 1187-1196. [Pubmed]

26. Okano T, Yamada N, Sakai H, Sakurai Y (1993) A novel recovery system for cultured cells using plasma-treated polystyrene dishes grafted with poly $(\mathrm{N}$ isopropylacrylamide). J Biomed Mater Res 27(10): 1243-1251.[Pubmed]

27. GEHAN EA (1961) The determinatio of the number of patients required in a preliminary and a follow-up trial of a new chemotherapeutic agent. J Chronic Dis 13: 346-353.[Pubmed]

28. Agresti A, Coull BA (1998) Approximate is better than 'exact' for interval estimation of binomial proportions. The American Statistician 52: 119-126.

29. Lavker RM, Tseng SC, Sun TT (2004) Corneal epithelial stem cells at the limbus: looking at some old problems from a new angle. Exp Eye Res 78(3): 433-446.[Pubmed]

30. Tsai RJ, Tseng SC (1994) Human allograft limbal transplantation for corneal surface reconstruction. Cornea 13(5): 389-400.[Pubmed]

31. Espana EM, Di Pascuale M, Grueterich M, Solomon A, Tseng SC (2004) Keratolimbal allograft in corneal reconstruction. Eye (Lond) 18(4): 406-417. [Pubmed]

32. Daya SM, Ilari FA (2001) Living related conjunctival limbal allograft for the treatment of stem cell deficiency. Ophthalmology 108(1): 126-133.[Pubmed]

33. Samson CM, Nduaguba C, Baltatzis S, Foster CS (2002) Limbal stem cell transplantation in chronic inflammatory eye disease. Ophthalmology 109(5): 862-868.[Pubmed]

34. Shimazaki J, Shimmura S, Fujishima H, Tsubota K (2000) Association of preoperative tear function with surgical outcome in severe Stevens-Johnson syndrome. Ophthalmology 107(8): 1518-1523.[Pubmed]

35. Holland EJ, Schwartz GS (2004) The Paton lecture: Ocular surface transplantation: 10 years' experience. Cornea 23(5): 425-431.[Pubmed] 